\title{
Not Known if ALK Rearrangement Analysis Was Performed
}

National Cancer Institute

\section{Source}

National Cancer Institute. Not Known if ALK Rearrangement Analysis Was Performed. NCI Thesaurus. Code C160430.

An indication that it is not known whether ALK rearrangement analysis was performed during the study. 